\title{
TEACHERS' PERSPECTIVES OF TEACHING ENGLISH TO YOUNG LEARNERS (A DESCRIPTIVE STUDY AT PRIMARY SCHOOLS IN KUDUS)
}

\author{
Sri Endang Kusmaryati \\ sri.endang@umk.ac.id \\ Universitas Muria Kudus, Indonesia
}

\begin{abstract}
In Indonesia teaching English at primary schools aims to introduce English language as a foreign language. Students of primary schools are young learners who have their own characteristics. Young learners take great pleasure in playing games. Therefore, teaching English for primaryschools students must be well designed in accordance with the characteristics of the students. This study is a survey that aims to investigate teachers' perspectives of teaching English to young learners in Kudus. Further, it inspects their problems in teaching English in their schools. A questionnaire is distributed to the targeting primary school teachers in Kudus. The result reveals that there are $67 \%$ of the teachers who agreed that English is appropriately taught at primary schools, while $33 \%$ of the teachers disagreed. Teachers' problems in teaching English to primaryschools students, among others are the limited time allotments, students' proficiencies in vocabulary and pronunciation, students' interests, limited facilities, textbook, media and learning materials, and too many students in the classroom. Besides, the primary school students are young learners who are very active and like to break the rules.
\end{abstract}

Keyword: Teachers' Perspectives, English to Young Learners

\section{INTRODUCTION}

Teaching English at primary school has become a crucial policy of education in Indonesia. The competence of primary schools' graduates should be appropriate in order to prepare them to learn English at the higher level. Teaching English at elementary schools is intended to develop basic language skills used as an introduction to know English as a foreign language.The Indoneian policy of Departmen Pendidikan Nasional, No.0487/14/1992, Chapter VIII and Undang-undang Sistem Pendidikan Nasional, No.060/U/1993 states that learning English in primary schoolsmay be integrated into the curriculum as a local content subject.However teachers must consider the English learning model appropriatelythat takes into account the child's developmental level. Besides, teachers also have a high effect on the students' achievements, because they give influencial factors to contribute the process of teaching and learning for the students. This article intents to highlight the level of the teachers' perspectives of the teaching English to young learners.

Students of primary schools are young learners who have their has different characteristics as adult learners. Young learners are really enjoyable in playing their games. They have a lot of imaginations and fantasies. The needs of prospectiveprimary school teachers in understanding their world and mastering English both in spoken and written. The teachers also needto have the ability to teach using English as the language of instruction in the teaching and learning process 
in the classroom. Besides, the English teachers of primary schools should be able to use English communicatively and have the skills to teach English effectively.

Some primary schools in Kudus determine English as a local content subject. In some schools, moreover, English has been taught in the first grade at the first semester. Therefore, teaching English for primaryschools students must be well designed based on their charactersitics in which they are still in the early age around six to eleven years old.

In reference to some personal conversations conducted by the researcher with some English teachers of primary schools in Kudus, it seems that the students are not really interested in studying English. It is hard for teachers in using games in teaching English, because the primaryschools students tend to be very active and like to play.

Classroom, as a place of teaching-learning interaction, is often called as an artificial environment for teaching, learning, and using a foreign language. However, the classroom is also a real social context in its own right, where learners and teacher come into the real social relationships with each other. In the classroom the students and teachers interact and give helps each other. The teaching-learning process is the interaction between teacher and students in which the value and quality of interaction in the teaching learning process set up students' learning achievement. A teacher is one of components of the classroom interaction and they have an important role in the teaching-learning process, that is to manage the classroom interaction. The teacher also has responsibility to create the classroom enjoyabe with certain activities and interactions well planned in order to achieve a certain behavioral outcome. In the classroom, the teachers can create enjoyable condition where the students can develop their abilities in learning English, especially to improve their skills for real communication. It implies how teachers create a relationschip between the teachers and students in a form of classroom interaction, for example when the teacher explains the materials, asks questions, gives feedback, and the students listen to the teacher's explanation, answer the questions, express their ideas, do the tasks and activities, and the rest.

This research aims to find out 1) the teachers' perspectives of teaching English to young learners, and 2) the teachers' problems in teaching English to primaryschools students.

\section{REVIEW OF RELATED LITERATURE}

Teaching English, especially English for young learners in Indonesia, has a special concern for educators of English. They are so attentive to the teaching and learning of the English language, including English for young learners especially at the primary schools. As mentioned previously that the teacher must consider the appropriate English learning that takes into account the child's developmental level ofprimary schools students. Teaching and learning English for them must be well designed in the form of curriculum, syllabus, teaching materials, media and strategies, and also the assessments.

For teacher, teaching English for young learners must consider the theories developed by Piaget, Vygotscky, and Bruner. According to Piaget via Cameron (2001: 2-4) the child is an active learner and thinker, constructing his or her own knowledge from working with objects or ideas. $\mathrm{He} / \mathrm{she}$ interacts with the world around him/her, solving problems presented by the environment. The child is also a sense make and has more attetions to what other people do. Vygotsky in Cameron (2001:5) says that development and learning take place in a social context. World is full of other people who play important role in helping children to learn, bringing objects and ideas to their attention, talking while playing and about playing, reading stories, asking 
questions. Children learn to do things and learn to think through interaction with adults in a social context in the Zone of Proximal Development (ZPD). Meanwhile Bruner via Cameron (2001:8-10) says that language is the most important tool for cognitive growth, and he has investigated how adults use language to mediate the world for children and help them to solve problems. Talks support a child in carrying out an activity, and it is called as scaffolding talks. The scaffolding talks can be transferred in the language classroom as routines which happen every day. It may provide opportunities for meaningful language development. They allow the child to actively make sense of new language from familiar experience and provide a space for language growth, and routines will open up many possibilities for developing language skills.

Teaching English at primary schools, especially for students in early ages will not be the same as teaching English for adult. Clark and Clark (1977) explained: Young learners are still in the process of developing their ideas. They learn what the school provides everythingfor them. They are in the process of learning many things at the same time. Students in early ages have their unique characteristics. They have a more concrete way of thinking, especially in foreign language learning. They do not need to study linguistics in detail, that is why the teaching of grammar is not necessary. Haliwell (1992) gives more description about the issue of learning English in early ages. According to him young learners have already great skills in using limited language creatively. In their ages, the capacity for conscious learning of grammatical forms and patterns is still relatively undeveloped. They learn language through the process of acquisition or subconscious more than the direct and conscious learning. When their environment is available to provide more things to learn, they will learn much. Young learners take great pleasure in finding and creating fun in themselves. their world is full of imagination and fantasy.

From Haliwell's explanation, it can be concluded that learning English for students in early ages need a way of fun or learning techniques in order to make them more interested in learning a foreign language, in this case English. Haliwell (1992) also describes that the characteristics of the early age children can generally be viewed in terms of cognitive, affective and psychomotor. From the cognitive aspect, the kids have had the ability to interpret the meaning. They have the power of attention and limited concentration. They already have the power of imagination. They understand the situation. While in the affective aspect, the kids are happy to find and create something. They love to talk. They love to play and work. They are interested in the activities that are relevant for them. On the other hand, from the aspect of psychomotor, children have skills in using limited language but creative. They can learn to do something. They learn English by using it. They can work together with adults. They will learn best when they are engaged in activities relevant to them. The students of primary schools are young learners who are around 6 to 12 years old. They have their own characteristics, as Nunan (2011: 12-13) describes in the following young learners' characteristics, namely: Imaginative, more confident-risk taker, love playing, imitating, reward for children's learning, short attention, and high curiosity.

Cameron (2001:1) describes that children are often more enthusiastic and lively as learners. They want to please the teacher rather than their friends. They like to do any activities eventhough they they do not know exactly why how to do, but they easlily lose their interest and keep theselves motivated when they find any difficulties.

In teaching English for young learners, language curriculum development should proceed from the needs of the learners as a base design developed. It is intended that the design developed appropriate or relevant and consistent with the goals of existing programs. Designing communicative competence must be considered by taking into account the textbook used in the classroom, especially in preparing learning materials and design of evaluation. 
By considering the characteristics of the young learners, the purpose of learning English to them in general can be defined as follows: first, the learning is intended to make children feel competent and confident in learning English. Second, learning should also be able to provide a safe learning environment, that is entertaining and recreation as well as educating. Third, learning English should be able to create English language learners in the long term. Moreover Philips (1993:5) describes that young learners have the advantage of being great mimics, are often unselfconscious, and are usually prepared to enjoy the activities the teacher has prepared for them. These factors mean that it is easy to maintain a high degree of motivation and to make the English class an enjoyable, stimulating experience for the children.

Looking the table above, the English teachers at primary schools should consider the ten suggestions to make the students achieve the communicative competence. Teaching English for young learners should be really designed based on their characteristics of young learners. Using appropriate media of teaching, choosing creative themes the students like, involving the students in interactive activities by using mimics or gestures are important to consider. Using English in the classroom as a routine can help them interact with the teacher, but sometimes the teacher can also use first language to help the understand the teaching materials. Besides, the teacher can collaborate with colleges or professionals to share opinions.

A teacher has a responsibility in making an interactive teaching learning process. When students respond to the teacher it means that they understand what the teacher explained. It can only happen if the teacher and students have a good quality of teaching learning process. Rivers (1991: 160-162) puts the importance of interaction in this way:

"Through interaction, students can increase their language sore as they listen to or read authentic material or oven the output of their fellow students in discussion, skits, join problem solving tasks, or dialogue journals. In interaction, students can use all the possess of the language, all they have learned or casually absorbed in real-life exchange. Even at anprimary stage, they learn in this way to exploit the elasticity of language".

Based on the explanation above, we know that the successful of learning process is mostly depends on the interaction in process of teaching and learning. Then, the students should be given more opportunity to speak, and share their ideas. Therefore, the understanding of the interaction between these elements is also very important.

Sometimes a teacher uses the traditional approach of teaching in which the learner used to be dependent only on the lecture delivered by the teacher. They are not exposed to enough practice of speaking on their own and hence the interaction among the students in the classroom was almost absent. But now education system demands more of students' interaction rather than just listening to the teacher.It is teachers' responsibility to create classroom interaction as a practice for the students to develop the two essential oral language skills, namely: listening and speaking, especially among the students.In this case, the teachers also need to provide many English expressions (classroom English) to fasilitate the students for the classroom interactions.

Classroom interaction can help the students to identify their own learning methods. It guides them to communicate with their friends easily and will give them an exposure to the vase genres of language learning, and it is really important to help the students to come face to face with the various types of interaction that can take place inside the classroom. Classroom Interaction aims at meaningful communication among the students in their target language. It also aims at 
probing into the learner's prior learning ability and their ways of conceptualizing facts and ideas. This practice will help the teacher to have a detailed study of the nature and the frequency of student interaction inside the classroom.

The role of the teacher during the interaction is very essential. It is the teacher responsibility to create a learning atmosphere inside the classroom. The teacher can extract responses from students and motivate them to come out with new ideas related to the topic. The teacher is an observer who helps them to construct an innovative learning product through group discussions, debates and many more. The teacher is also as a planner who plans out the best modules of interaction that would be effective to invite the students in classroom interaction. Through classroom interaction the students will be able to get themselves involved with concepts, ideas and various other devices and products for language and culture learning.

There are different types of classroom interaction that can be used to vary the the activities in the classroom. The teachers can make the whole class working together on projects or games, while the teachersfacilitate their activities. Sometimes, teachers can assign a student to be in charge to run a game, and others can sit with the class to be participants. Creating various types of classroom interactions used in the English class can help the students stay interested.

Teacher's feedbackand correction are also important for classroom interaction to improve the students' achievements. Teachers can give feedback and correction in spoken or written. They can do it individually in front of the class, or ask general suggestion and correction from the other students. However, the teachers also need to know some students may not be confortable when the receive individual feedback and correction in front of the other students.

As described previously, this article focuses on the teachers' perspectives on teaching English in primary schools. Perspectives is perceptions that means the ability to realize the object or phenomenon by using five senses. Rakhmat (2013) describes that perception is the first step of receiving information called as sensation through the senses. People have five senses to receive information from the environment. A person acquires the knowledge and all of the ability to interact in the real situation. Every person has different perceptions about something. that influence someone's perception as mentioned by Robbin and Judge (2008) mention the aspects that influence someone's perception as follows.

1. The perceiver is the person who is trying to interpret what he or she observes around them by using his or her senses. The aspects that affect such as behavior, motive, interest, experience, and expectation.

2. The target of perception is the target of the perceiver, it can be a person, a group, a situation, an event, or an idea. It can be something new, movement, size, sound, proximity, background, or similarity.

3. The situation is the context in which the perception takes place. It can be time, social setting, work.

For English as a Foreign Language (EFL) teachers, to be effective in their classes, they require basic competencies as Richards (2011) determinedthe ten core aspects of language teaching expertise and practice, namely: language proficiency, content knowledge, teaching skills, contextual knowledge, language teacher's identity, student-focused teaching, pedagogical reasoning skills, theorizing from practice, membership of a community of practice and professionalism. 
According to Richards (2011) in the process of teaching English, teachers also need to consider the social and ultural context of learning environment. When teachers find themselves in a surrounding of the classroom, they must adapt all the competencies mentioned above to fit this context. Further, they should understand well the characteristics and psychological background of the students. The teachers need to understand how to integrate the theory into classroom practice. Hence, teachers of young learners should pay attentionmore to the essesntial factors concerning the characteristics of the age group they are teaching. As Cameron (2003) described that unlike adults, young learners cannot analyze language in an abstract way. They cannot use their knowledge of different contexts to guess meanings of language.Based on that kind of situation, knowing the teachers' perspectives of teaching English to young learners is assential to research.

\section{METHOD}

It is a descriptive qualitative research surveying the teachers' perspectives of teaching English to young learners. The descriptive research was conducted through collecting the teachers' responses to the questionnaire that was developed for this purpose. The data of this research are the teachers' perspectives of teaching English to young learners. The data will be collected through a questionnaire. The questionnaire that was designed by the researchers consists of two main sections. The first was Teacher's perspectives of teaching English to young learners and their problems in teaching English to primaryschools students. The data source is the teachers who teach English at 37 state primary schools in Kudus in academic year 2016/2017. Descriptive statistics were used and computed. Open responses were also gathered and analyzed. Tables will summarize the percentage of responses to each section of the questionnaire.

\section{FINDINGS}

This chapter describes the three sections of the data, namely: the teachers perceptions of teaching English in primary school, their problems in teaching English to primary schools students, and the suggestions to overcome the problems.

\section{Teachers' Perspectives of Teaching English to Young Learners}

The data of the teachers' perceptions of teaching English at primary schools in Kudus is presented in the following table.

Table 1. Teachers' Perceptions of Teaching English in Primary Schools

\begin{tabular}{clccl}
\hline \multirow{2}{*}{ NO } & NAME OF SCHOOL & \multicolumn{2}{c}{ PERCEPTION } & \multirow{2}{*}{ REASONS } \\
\cline { 3 - 4 } 1. & & Agree & Disagree & \\
\hline 1. & SD 5 Jekulo & & $\sqrt{ }$ & Limited proficiency of English teachers. \\
\hline 2. & SD 1 Bulung & $\sqrt{ }$ & & $\begin{array}{l}\text { English is needed as a means of } \\
\text { communication in this era. }\end{array}$ \\
\hline 3. & SD 3 Bulung & & $\sqrt{ }$ & $\begin{array}{l}\text { Primary school students just need basic } \\
\text { English for future study. }\end{array}$ \\
\hline 4. & SD 4 Bulung & $\sqrt{ }$ & & But not too many assignments \\
\hline 5. & SD 7 Bulung & $\sqrt{ }$ & & Using English as a habit. \\
\hline
\end{tabular}




\begin{tabular}{|c|c|c|c|c|}
\hline 6. & SD $1 \mathrm{Bae}$ & $\sqrt{ }$ & & For future study \\
\hline 7. & SD 2 Bae & & $\sqrt{ }$ & $\begin{array}{l}\text { Because it makes students difficult to } \\
\text { understands }\end{array}$ \\
\hline 8. & SD $3 \mathrm{Bae}$ & & $\sqrt{ }$ & $\begin{array}{l}\text { Because it makes students difficult to } \\
\text { understands }\end{array}$ \\
\hline 9. & SD 4 Bae & & $\sqrt{ }$ & - \\
\hline 10. & SD 5 Bae & $\sqrt{ }$ & & For communication \\
\hline 11. & SD 6 Cendono & $\sqrt{ }$ & & To make the students accustomed with it. \\
\hline 12. & SD 3 Kajar & $\sqrt{ }$ & & $\begin{array}{l}\text { In order to make the students accustomed } \\
\text { with it. }\end{array}$ \\
\hline 13. & SD 1 Colo & $\sqrt{ }$ & & $\begin{array}{l}\text { In order to make the students accustomed } \\
\text { with it. And also to help students speak } \\
\text { English more. }\end{array}$ \\
\hline 14. & SD 1 Lau & $\sqrt{ }$ & & $\begin{array}{l}\text { In order to make the students accustomed } \\
\text { with it. And also to help students speak } \\
\text { English more. }\end{array}$ \\
\hline 15 . & SD 2 Kajar & & $\sqrt{ }$ & $\begin{array}{l}\text { Because they have lack of understanding } \\
\text { about English }\end{array}$ \\
\hline 16. & $\begin{array}{l}\text { SD 01 Purwosari } \\
\text { Kudus }\end{array}$ & $\sqrt{ }$ & & English is an international language. \\
\hline 17. & SD 02 Purwosari & & $\sqrt{ }$ & $\begin{array}{l}\text { Teachers need to arouse the students' } \\
\text { interest in learning English. }\end{array}$ \\
\hline 18. & SD N Demangan & & $\sqrt{ }$ & Students need to learn English vocabulary \\
\hline 19. & SD 1 LoramWetan & $\sqrt{ }$ & & $\begin{array}{l}\text { Learning English vocabulary to develop } \\
\text { science. }\end{array}$ \\
\hline 20. & SD 2 LoramWetan & & $\sqrt{ }$ & Many students do not understand English \\
\hline 21. & SD 3 Loram & & $\sqrt{ }$ & No interest and parents attentions \\
\hline 22. & SD 4 GetasPejaten & $\sqrt{ }$ & & To make the students accustomed \\
\hline 23. & SD 4 Mejobo & $\sqrt{ }$ & & $\begin{array}{l}\text { Because the students are easier to } \\
\text { remember English. }\end{array}$ \\
\hline 24. & SD 1 Mejobo & $\sqrt{ }$ & & $\begin{array}{l}\text { Because the students are easier to } \\
\text { memorize English }\end{array}$ \\
\hline 25. & SD 3 Payaman & $\sqrt{ }$ & & Because it can make students habit. \\
\hline 26. & SD 1Kesambi & & $\sqrt{ }$ & Because at school in the village. \\
\hline 27. & SD 2 Getassrabi & $\sqrt{ }$ & & Students are easy to learn English \\
\hline 28. & SD 1 Padurenan & $\sqrt{ }$ & & As a habit for the students \\
\hline 29. & SD 1 Karangmalang & $\sqrt{ }$ & & $\begin{array}{l}\text { To make the students habit in using } \\
\text { English }\end{array}$ \\
\hline 30 . & SD 4 Kalirejo & $\sqrt{ }$ & & $\begin{array}{l}\text { To make the students able to interact with } \\
\text { others by using English. }\end{array}$ \\
\hline 31. & SD 2 Medini & $\sqrt{ }$ & & $\begin{array}{l}\text { To make the students have a habit of } \\
\text { speaking in English }\end{array}$ \\
\hline 32. & SD 3 Sambung & $\sqrt{ }$ & & $\begin{array}{l}\text { But it is not a must, because English in the } \\
\text { primary school is still in introduction level } \\
\text { for the next education level. }\end{array}$ \\
\hline 33. & SD 3 Undaan Tengah & $\sqrt{ }$ & & $\begin{array}{l}\text { Because English is an international } \\
\text { language. }\end{array}$ \\
\hline 34. & SD 2 Kaliwungu & $\sqrt{ }$ & & $\begin{array}{l}\text { Because English as the international } \\
\text { language to communicate in the world }\end{array}$ \\
\hline 35 . & SD 2 Kedungdowo & $\sqrt{ }$ & & $\begin{array}{l}\text { Because it can make students speak } \\
\text { English fluently. }\end{array}$ \\
\hline 36. & SD 1 GarungLor & $\sqrt{ }$ & & Because to practice the students in English \\
\hline
\end{tabular}




\begin{tabular}{cccc} 
37. SD 1 PrambatanKidul & $\checkmark$ & $\begin{array}{c}\text { Because English is as the international } \\
\text { language }\end{array}$ \\
\hline TOTAL & 25 & 12 & \\
& $(67 \%)$ & $(33 \%)$ & \\
\hline
\end{tabular}

From the table of the teachers'perceptions of teaching English at primary schools in Kudus, there are $67 \%$ of the teachers who agreed that teaching English at primary schools is important with different reasons. Some of them have opninions that English as an international language, teaching English to primary schools students make the students speak English fluenly. The students can practice English well as a habit. Besides, 33\% of the teachers disagreed that English is taught at primary schools. In their opinions, English is difficult to study for the students, they still have low proficiencies and interests.

As mentioned in the previous chapter, teaching English to primary schools students as young learnersare not the same as teaching English for adult. Cameron (2001:1) describes that children are often more enthusiastic and lively as learners and also lose interest more easily. That is why teachers must consider the appropriate English learning that is the learning that takes into account the child's developmental level. It is not easy for teachers to handle the characteristics of the students in early ages. Teachers need to have a great patience and creative to conduct the process of teaching and learning in the classroom for them. The role of the teacher to createthe interactionin the process of teaching and learning is very crucial. It is the teacher responsibility to create a learning atmosphere inside the classroom. The teacher can extract responses from learners and motivate them to come out with new ideas related to the topic. The teacher is an observer who helps the learners to construct an innovative learning. The teacher is also a planner who invite the learners in classroom interaction.More teachers $(67 \%)$ agreed that teaching English is important for primary schools students, but some of them (33\%) disagreed. They have different perceptions, because they may have different knowledge about the characteristics of the primary school students as young learners, and also different capabilities to manage the classroom interactions for the students.

\section{Teachers' Problems in Teaching English toPrimary School Students}

The data of the teachers' problems in teaching English to primary school Students is described in the following table.

Table 2. Teachers's Problem in Teaching English to Primary School Students

\begin{tabular}{llll}
\hline NO. & NAME OF SCHOOL & \multicolumn{1}{c}{ PROBLEMS } & \multicolumn{1}{c}{ DESCRIPTION } \\
\hline 1. & SD 5 Jekulo & Vocabulary \& Interest & $\begin{array}{l}\text { The students are still difficult to } \\
\text { understand the vocabulary, so they are not } \\
\text { interested in learning English. }\end{array}$ \\
\hline 2. & SD 1 Bulung & Teaching materials & $\begin{array}{l}\text { The students are still difficult to } \\
\text { understand the teaching materials. }\end{array}$ \\
\hline 3. & SD 3 Bulung & $\begin{array}{l}\text { Limited media and } \\
\text { learning source }\end{array}$ & $\begin{array}{l}\text { The media and learning source are still } \\
\text { limited in the school. }\end{array}$ \\
\hline 4. & SD 4 Bulung & Too many students & $\begin{array}{l}\text { There are too many students in the } \\
\text { classroom and they have different } \\
\text { proficiencies. }\end{array}$ \\
\hline 5. & SD 7 Bulung & Vocabulary & $\begin{array}{l}\text { The students do not have enough English } \\
\text { Vocabulary. }\end{array}$ \\
\hline 6. & SD 1 Bae & Pronunciation & $\begin{array}{l}\text { The students are difficult to pronounce } \\
\text { words in English }\end{array}$ \\
\hline
\end{tabular}




\begin{tabular}{|c|c|c|c|}
\hline 7. & SD 2 Bae & Pronunciation & $\begin{array}{l}\text { The students are difficult to pronounce the } \\
\text { English vocabulary and reading text }\end{array}$ \\
\hline 8. & SD $3 \mathrm{Bae}$ & Pronunciation & $\begin{array}{l}\text { The students are difficult to pronounce the } \\
\text { vocabulary and reading text }\end{array}$ \\
\hline 9. & SD 4 Bae & Materials & $\begin{array}{l}\text { The materials are too difficult to } \\
\text { understand for students }\end{array}$ \\
\hline 10. & SD $5 \mathrm{Bae}$ & Materials & $\begin{array}{l}\text { The materials are too difficult to } \\
\text { understand for the students }\end{array}$ \\
\hline 11. & SD 6 Cendono & $\begin{array}{l}\text { Limited English } \\
\text { textbooks }\end{array}$ & $\begin{array}{l}\text { There are limited amount of English } \\
\text { textbooks. }\end{array}$ \\
\hline 12. & SD 3 Kajar & $\begin{array}{l}\text { Too active, like to } \\
\text { break the rules }\end{array}$ & $\begin{array}{l}\text { The students sometimes like to break the } \\
\text { rules and act as they want. }\end{array}$ \\
\hline 13. & SD 1 Colo & $\begin{array}{l}\text { Too active, like to } \\
\text { break the rules }\end{array}$ & $\begin{array}{l}\text { The students are sometimes difficult to be } \\
\text { commanded and ordered because they act } \\
\text { as they want. }\end{array}$ \\
\hline 14. & SD $1 \mathrm{Lau}$ & $\begin{array}{l}\text { Environment, facilities, } \\
\text { \& limited time } \\
\text { allotment }\end{array}$ & $\begin{array}{l}\text { The environment is not really good, lack of } \\
\text { teaching facilities, and limited time } \\
\text { allotment in teaching and learning process }\end{array}$ \\
\hline 15. & SD 2 Kajar & $\begin{array}{l}\text { Students' lack } \\
\text { understanding } \\
\text { Too active, break the } \\
\text { rules }\end{array}$ & $\begin{array}{l}\text { The students have lack understanding } \\
\text { about English, and sometimes like to break } \\
\text { the rules and act as they want }\end{array}$ \\
\hline 16. & SD 01 Purwosari & Pronunciation & $\begin{array}{l}\text { The students are difficult to pronounce } \\
\text { English. }\end{array}$ \\
\hline 17. & SD 02 Purwosari & $\begin{array}{l}\text { Students proficiencies } \\
\text { Interest, and facilities }\end{array}$ & $\begin{array}{l}\text { The students have low proficiencies and } \\
\text { interest. Thereare no supported facilities. }\end{array}$ \\
\hline 18. & SD N Demangan & Teaching media & The teaching media is still limited \\
\hline 19. & SD 1 LoramWetan & $\begin{array}{l}\text { Vocabulary \& } \\
\text { Pronunciation }\end{array}$ & $\begin{array}{l}\text { The students have limited vocabulary and } \\
\text { and hard to pronounce English words }\end{array}$ \\
\hline 20. & SD 2 LoramWetan & Students' Proficiencies & $\begin{array}{l}\text { The students sometimes can not } \\
\text { understand English. }\end{array}$ \\
\hline 21. & SD 3 Loram & Students' interests & The students have low interest. \\
\hline 22. & SD 4 GetasPejaten & $\begin{array}{l}\text { Facilities and teaching } \\
\text { media }\end{array}$ & $\begin{array}{l}\text { The facilities and teaching media are } \\
\text { limited. }\end{array}$ \\
\hline 23. & SD 4 Mejobo & Teaching media & $\begin{array}{l}\text { The school has limited facility, especially } \\
\text { picture. }\end{array}$ \\
\hline 24. & SD 1 Mejobo & Facilities & The school has minimum facilities. \\
\hline 25. & SD 3 Payaman & Facilities & $\begin{array}{l}\text { The school has minimum facilities and the } \\
\text { students don't have good understanding. }\end{array}$ \\
\hline 26. & SD 1Kesambi & Limited time allotment & There is no additional time.. \\
\hline 27. & SD 2 Getassrabi & Too Active & The class tends to be so noisy. \\
\hline 28. & SD 1 Padurenan & $\begin{array}{l}\text { Too active \& } \\
\text { Vocabulary }\end{array}$ & $\begin{array}{l}\text { The students sometimes run around the } \\
\text { class. The have limited vocabulary. }\end{array}$ \\
\hline 29. & SD 1 Karangmalang & $\begin{array}{l}\text { Students proficiency\& } \\
\text { too many students }\end{array}$ & $\begin{array}{l}\text { The student can not understand English. } \\
\text { There are too many students in the } \\
\text { classroom. }\end{array}$ \\
\hline 30. & SD 4 Kalirejo & Limited time allotment & The time allotment is limited. \\
\hline 31. & SD 2 Medini & Students' interest & The students' interests are still limited. \\
\hline 32. & SD 3 Sambung & Students' proficiency & $\begin{array}{l}\text { Delivering the material by using English is } \\
\text { still difficult for the students to understand. }\end{array}$ \\
\hline 33. & SD 3 UndaanTengah & $\begin{array}{l}\text { Classroom } \\
\text { management }\end{array}$ & $\begin{array}{l}\text { Organizing the class is still difficult for the } \\
\text { teacher. }\end{array}$ \\
\hline 34. & SD 2 Kaliwungu & Students' interests & The students' interests are still low. \\
\hline
\end{tabular}




\begin{tabular}{llll}
\hline 35. & SD 2 Kedungdowo & Too active & The students are busy with themselves. \\
\hline 36. & SD 1 GarungLor & Learning materials & $\begin{array}{l}\text { Absorbing the materials from the teacher } \\
\text { to the students are still low }\end{array}$ \\
\hline 37. & SD 1 PrambatanKidul & Too active & The students are busy with themselves \\
\hline
\end{tabular}

Table above describes the problems faced by the teacher in teaching English to primary schools students. The problems among others are about the limited time allotments, students' proficiencies in vocabulary and pronunciation, students's interests, limited facilities, textbook, media and learning materials, and too many students in the class. Besides, the primary school students are young learners who are very active and like to break the rules.

Characteristics of primary school students as young learners who are around 6 to 12 years old tend to be very active. Haliwell (1992) explains the issue oflearning English in early ages that young learners already have great skills in using limited language creatively. In the early stages of their mother tongue development, children are excellent at making a little language go along away. In their ages, the capacity for conscious learning of grammatical forms and patterns is still relatively undeveloped.

Knowing this condition, teachers need to have more knowledge about the characteristics of their students as young learners. Moreover, teachers also need more time allotment, textbooks, media, and learning materials to facilitate the process of teaching and learning in the classroom. All this facilities are actually to support in improving students' English profeciencies, especially in grammar and pronunciation. Teachers also need to have innovative strategies to motivate and arose the students' interests in learning English.

\section{CONCLUSIONS}

Teachers' perspectives of teaching English at primary schools shows there are $67 \%$ of the teachers who agreed English is taught at primary schools. They think that English, as an internationan language, must be studied as early as possible to make the students of primary schools accustomed with English. The students are still in golden ages, so it is easier for them to memorize the vocabularies and speak English fluently. Besides, When studying English becomes a habit, it will help them to study in the future level. In another side, $33 \%$ of the teachers disagreed that English is taught in primary schools, because Kudus is a rural area, they still have low proficiencies and interests. Moreover, the teachers tend to have limited proficiency of English.

The teachers have problems in teaching English to primary schools students. The time allotments of teaching English is limited. The students' proficiencies in vocabulary and pronunciation are low. Moreover, the schools' facilties, textbooks, media and learning materials are also limited. Too many students in the classroom and the very active students who like to break the rules become the problems also for the teachers.

\section{REFERENCES}

Borich, C.D. (1996). Effective TeachingMethods. New Jersey: Prentice-Hall Inc.

Brown, H. D. (2000). Principles of LanguageLearning and Teaching.New York: Addison Wesley Longman Inc.

Brown, H. D. (2007). Teaching by Principles: An InteractiveApproach to LanguagePedagogy. New York: Wesley Inc 
Cameron, L. (2001). Teaching Language to YoungLearners. Cambridge: Cambridge University Press.

Cameron, L. and Penny Mckay. (2010). Bridging Creative Teachinginto theYoungLearner Classroom.New York: Oxford University Press.

Celce-Murcia, M. (Ed.) (1991). Teaching English as a Second or Foreign Language.(2nd ed.). Boston: Heinle and Heinle

Clark, H.M., and E.V. Clark .(1977). Psychology and Language: An Introduction to Psycholinguistics. New York: Harcount Brace Jovanovich.

Depdiknas. (1992). Policy of DepartemenPendidikanNasional, No.0487/14/1992.

Depdiknas. (1993). Undang-undang System PendidikanNasional, No.060/U/1993

Desmita. (2005). PsikologiPerkembangan. Bandung: RemajaRosdakaya.

Grave, K.(2000).Designing LanguageCourses: A Guide for Teachers. Canada: Heinle\&Heinle Publishers

Joan Kang Shin. Ten HelpfulIdeas for Teaching English to YoungLearners. An article in the English Teaching Forum.(Volume 44, No. 2).published by the U.S. Department of State's Office of English Language Programs.

Krashen, S.D. (1987). Language Acquisition and LanguageEducation. Great Britain: Prentise Hall International Ltd.

Krashen, S.D. (2002). Second LanguageAcquisition and SecondLanguageLearning. California: Pergamon Press Inc.

Mckay, S. L. and Rani R.The Social and SociolinguisticContextsInlanguageLearning and Teaching.InLong, M. H, and Catherine J. D. (2009).The Handbook of LanguageTeaching. Singapore: Blackwell Publishing Ltd.

McFarland, R. A. (1981). Physiological Psychology: The Biology of HumanBehavior. Mayfield Publishing Company.

Nunan, D. (2011). Teaching English to YoungLearners.New york: Anaheim University Press.

Philips, S. (1993). Young Learners. New York: Oxford University Press.

Robbins, P. S. \&Timothi, A, J. (2008). PerilakuOrganisasi. Jakarta: SalembaEmpat

Savignon,S.J. Communicative LanguageTeaching: Strategies and Goals. In Hinkle, E.(2005).Handbook of Study in SecondLanguageTeaching and Learning.(Volume I). London: Lawrence Erlbaum Associates, Publishers.

Slattery, M. and Jane Willis. (2009). English for Primary Teachers: A Handbook of Activities and Classroom Language.New York: Oxford University Press. 